The Guide follows the modern format which has now entirely replaced the rather text-book-like editions of earlier days. A useful plan of the ground floor is followed by a short historical sketch of the Museum and a description of the exhibits in the Central Hall including the bays together with an outline of the chief features in the Geological, Zoological and Mineralogical Galleries. As the Botanical Gallery is at present under reconstruction, the only botanical exhibits shown are those in the bays of the North Hall. The Guide is well illustrated and includes useful details concerning the library, other publications, the Children's Centre and general information about the Museum.

\section{Science in Antarctica}

AN interesting assessment of the need for future research programmes in Antaretica has recently been produced by the U.S. Committee on Polar Research of the National Academy of Sciences-National Research Council (Science in Antaretica: A Report by the Committee on Polar Research. Part 1: The Life Sciences in Antarctica. Pp. xi+162. Part 2: The Physical Sciences in Antarctica. Pp. xi+131. (Publications Nos. 839 and 878.) (Washington, D.C. : National Academy of Sciences-National Research Council, 1961.) 1.50 dollars each part). The Committee has drawn on leading scientists in the United States to write individual chapters, in each of which the present state of knowledge in a particular discipline is outlined, and possibilities of future developments of research in that field are discussed.

The length of individual chapters, excluding the useful bibliographies, varies from two pages on the "General Ecology and Physiology of Antarctic Fishes" and the "Antarctic Magnetic Programme" to sixteen pages on "Antarctic Glaciology". The report has been published in two parts, and it is of interest to note that Part 1, dealing with "The Life Sciences in Antarctica,", covers 162 pages compared with 131 pages on "The Physical Sciences in Antarc. tica". Although this is due partly to more detailed bibliographies covering the life sciences, it also serves to indicate the increased emphasis which the U.S. Committee on Polar Research would like to place on these disciplines which received little support during the International Geophysical Year. In fact, the introduction points out that the contributions of the United States to Antarctic biology are not great compared with those of other countries, and they hope that the present report will publicize the excel. lent opportunities in such fields for workers in the United States. The report on physical sciences includes chapters on cartography and geology, two fields of work not included in the programme for the International Geophysical Year. These are included under the section on the "Earth's Crust and Core"; other sections cover the "Heat and Water Budget of Antarctica" and "The Upper Atmosphere". The report has been produced primarily to stimulate interest among scientists within the United States in their Antarctic programme, as well as to emphasize the need for such an effort. It also forms a most useful reference source for scientific administrators connected with Antarctic programmes. The distribution of such reports outlining views of leading scientists on the most promising lines of research during the next five years is in keeping with the best traditions of science and the general atmosphere of international scientific co-operation in Antarctic matters which now prevails.

\section{Nuclear Geochronology}

Throughour the world more than a thousand research workers are engaged at present in determining the ages of rocks and minerals by methods based on radioactive decay, and as a consequence of this extensive activity it has of late become increasingly difficult for the average geologist to keep track of the many advances in absolute geochronology. Nonspecialists will therefore be indebted to two new works which summarize the latest progress in this field. The New York Academy of Sciences has just published the record of last year's conference on "Geochronology of Rock Systems", edited by Prof. J. L. Kulp of Columbia University, to which more than seventy workers of many nationalities have made contributions (Annals of the New York Academy of Sciences. Vol. 91, Article 2. Pp. 159-594. New York; New York Academy of Sciences, 1961). Simultaneously, the Academy of Sciences of the U.S.S.R. has issued a lengthy volume in Russian on Yadernaya Geokhronologiya or "Nuclear Geochronology" (630 pp., 1961. Price 3.13 new roubles. Moscow, Academy of Sciences of the U.S.S.R.) which is the work of Dr. I. E. Starik of the Radium Institute in Leningrad. One of the most significant features of these publications is a growing recognition of the extent to which apparent ages are dependent on metamorphic history. A new geochronological timescale produced by Dr. Starik from Russian evidence is in tolerably good (but far from complete) concurrence with the Holmes-Kulp chronology of the geological systems announced last year, and elaborated lately by Prof. Kulp in a comprehensive review contributed to Science (133, pp. 1105-1116, April 16, 1961). Both the American and Russian time-scales agree that the Silurian period, with a duration of only 20 million years, is by far the shortest in Palæozoic time-a conclusion which must surely cause Murchi. son to turn in his grave.

\section{Conservation of Water}

The sixth annual report of the Tweed River Purification Board covers the year ending May 15. 1960 , and thus deals with events occurring during the dry summer of 1959 (Pp. 39. Newton St. Boswells: Tweed River Purification Board, 1960). In this connexion the Board is concerned with the increasing demands being made on available water supplies-in particular, the use of spray irrigation by farmers may consume very large quantities, and the Board considers that legislation on this subject should be introduced at an early date. The value of the re-use of water by industry was exemplified at some sand and gravel washing plants in the Board's area-in some cases streams would have been pumped dry and production would have been restricted if the washing water had not been re-used. It is encouraging that the report records that rivers were in a generally cleaner condition, and fish mortality in the main rivers was substantially less than during the dry conditions of $1956-57$.

\section{Cambridge Rheology Club}

The first discussion meeting of the Cambridge Rheology Club, which was inaugurated on April 24. was held on May 29 at the Technological Research Station, Spillers, Ltd., Cambridge. Dr. J. R. A. Pearson (Department of Chemical Engineering, University of Cambridge), the chairman for the evening, welcomed the two visitors. Dr. M. A. 